(2) Open Access Full Text Article

\title{
Pharmacy students' attitudes toward pharmaceutical care in Qatar
}

\author{
This article was published in the following Dove Press journal: \\ Therapeutics and Clinical Risk Management \\ 18 February 2014 \\ Number of times this article has been viewed
}

\author{
Maguy Saffouh El Hajj' \\ Ayat S Hammad' \\ Hebatalla M Afifi ${ }^{2}$ \\ 'College of Pharmacy, Qatar \\ University, Doha, Qatar; ${ }^{2}$ National \\ Centre for Cancer Care and Research \\ (NCCCR), Doha, Qatar
}

Objectives: The study objectives were to investigate Qatar pharmacy students' attitudes toward pharmaceutical care (PC), to identify the factors that influence their attitudes, and to recognize their perceived barriers for PC provision.

Methods: A cross-sectional and online survey of Qatar pharmacy students was conducted.

Results: Over 4 weeks, 46 surveys were submitted (88\% response rate). All respondents agreed that the pharmacist's primary responsibility is to prevent and resolve medication therapy problems. Most respondents believed that PC provision is professionally rewarding and that all pharmacists should provide PC (93\% and $91 \%$ of respondents, respectively). Highly perceived barriers for PC provision included lack of access to patient information (76\%), inadequate drug information sources (55\%), and time constraints (53\%). Professional year and practical experience duration were inversely significantly associated with four and five statements, respectively, out of the 13 Standard Pharmaceutical Care Attitudes Survey statements, including the statements related to the value of PC, and its benefit in improving patient health and pharmacy practitioners' careers.

Conclusion: Qatar pharmacy students had positive attitudes toward PC. Efforts should be exerted to overcome their perceived barriers.

Keywords: Qatar, pharmaceutical care, pharmacy, student

\section{Introduction}

Recently, the focus of the pharmacy profession has shifted from medication supply to direct patient care. Pharmacists have been increasingly encouraged to broaden their role to include pharmaceutical care (PC) provision. PC is a multifactorial and structured process that is defined per Hepler and Strand as: "the responsible provision of drug therapy for the purpose of achieving outcomes that improve a patient's quality of life." It involves pharmacists working closely with patients and other health care professionals in three major functions: 1) detecting drug therapy problems, 2) resolving actual drug therapy problems, and 3) preventing potential drug therapy problems. Several studies have demonstrated that PC implementation improves patients' health outcomes and decreases health costs..$^{2-5}$ In response to the changing demands of the pharmacy profession, several professional pharmacy organizations internationally have adapted the philosophy of PC. ${ }^{6-8}$ Yet, several barriers have hampered the implementation of PC practice universally, including: insufficient time to provide PC, lack of pharmacists' self-confidence, inadequate clinical knowledge, and communication skills of pharmacists. Furthermore, the negative attitudes of pharmacists themselves toward
Correspondence: Maguy S El Hajj

College of Pharmacy, Qatar University,

Doha, Qatar 2713

Tel +974 44035577

Fax +974 4403555 I

Email maguyh@qu.edu.qa
Dovepress

http://dx.doi.org/10.21 477/TCRM.S56982
Therapeutics and Clinical Risk Management 2014:10 121-129

(c) (i) (\$) ๑ $2014 \mathrm{El} \mathrm{Hajij} \mathrm{et} \mathrm{al.} \mathrm{This} \mathrm{work} \mathrm{is} \mathrm{published} \mathrm{by} \mathrm{Dove} \mathrm{Medical} \mathrm{Press} \mathrm{Limited,} \mathrm{and} \mathrm{licensed} \mathrm{under} \mathrm{Creative} \mathrm{Commons} \mathrm{Attribution} \mathrm{-} \mathrm{Non} \mathrm{Commercial} \mathrm{(unported,} \mathrm{v3.0)}$ 
performing PC have served as barriers to providing PC. ${ }^{9-14}$ In addition to addressing the time barrier, to fully implement the practice of $\mathrm{PC}$, it is vital to prepare not only pharmacy practitioners of today but most notably the pharmacy practitioners of tomorrow. Many studies have described the role that pharmacy school educators should play in supporting the development of PC practitioners. ${ }^{15-20}$ They should design educational strategies that foster the development of pharmacists who are eager to implement PC in their practice. They are charged with the task of ensuring that students have a deep understanding of the PC principles and practices. ${ }^{21}$ In addition, they should instill in students good clinical knowledge, outstanding communication and problem solving skills, and self-confidence to take the responsibility for performing PC. What is challenging for pharmacy educators is to motivate pharmacy students to provide PC. By nurturing positive attitudes of students toward PC, pharmacy educators will be able to increase the provision of $\mathrm{PC}$ in practice. $^{22}$

Qatar is a sovereign Arab state located in the Gulf Region of the Middle East. It has approximately 1.8 million residents (2010 estimate) and occupies around 11,000 km of the northeasterly coast of the Arabian Peninsula. ${ }^{23}$ The health system in Qatar is in a state of major reform and restructuring. The health care facilities in this country are predominantly governmental, offering their services to citizens and residents. These facilities are mainly operated by health care professionals who received their training and education outside Qatar.

In the pharmacy sector, there are around 800 pharmacists who are working in different pharmacy practice settings including hospitals, community pharmacies and clinics. Around 55\% are male pharmacists, and more than $70 \%$ obtained their highest pharmacy degree from one of four countries: Egypt, Jordan, India, and Sudan. ${ }^{24,25}$ With the exception of rare patient oriented cognitive services, pharmacy practice in Qatar focuses mainly on medication dispensing, and PC is still in its infancy. ${ }^{26}$

In an effort to support the training of local graduates and improve pharmacy practice, in 2007, the college of pharmacy was established at the only national institution in the country, Qatar University (QU). ${ }^{24}$ QU College of Pharmacy is the first and only pharmacy degree program in the State of Qatar. It is accredited by Canadian Council on Accreditation of Pharmacy Programs. In addition to offering a 5-year Bachelor of Science in Pharmacy (BSc [Pharm]) degree program, in September 2011 the college started offering a Doctor of Pharmacy (PharmD) degree program and a Master of Sciences (MSc [Pharm]) degree program in the pharmaceutical sciences. The college accepts in its first professional year between 20 and 25 undergraduate female students per year. Acceptance into the college is by a competitive application process. Applicants must finish at least 33 credit-hours of pre-pharmacy courses prior to entering the pharmacy program. In addition, they have to sit the Pharmacy College Admission Test. Qualified applicants then undergo a formal interview by the college admissions committee. In 2011, the college graduated the first students to receive pharmacy degrees in the State of Qatar. ${ }^{27}$

One of the college missions is to prepare pharmacy students to provide optimal PC and advance health care outcomes. According to the college curriculum, the concept of PC is introduced in the first professional year through pharmacy and health care and professional skills courses. In these courses, pharmacy students learn about the PC concept through didactic lectures. Starting with the second professional year, the concept of PC is integrated through simulated case scenarios in several courses, including pharmacotherapy and professional skills courses, and through structured practical experiences in pharmacy (SPEP) (ie, pharmacy clerkships). Some of these scenarios are accessed using patient medical record software by Cerner's Academic Education Solution ${ }^{\circledR}$ (Cerner, North Kansas City, MO, USA), which simulates virtual patients for the students to gain PC experience working with electronic medical records.

SPEP involves 24 weeks (960 hours) of structured pharmacy practice experience in a community, hospital, or clinic pharmacy practice setting. The first SPEP takes place during the summer semester of the second professional year and is comprised of 160 contact-hours (4 weeks) of clerkships. The second SPEP occurs during the summer semester of the third professional year and includes 160 contact-hours (4 weeks) of clerkships. The remaining SPEPs occur during the fall semester of the fourth professional year and are comprised of 640 contact-hours $(4 \times 4$ weeks $)$ of clerkships. ${ }^{27}$

There is a need to confirm whether the education and training that QU College of Pharmacy students are receiving are good enough to nurture positive attitudes toward PC.

In fact, nothing is known about the attitudes of pharmacy students to PC in Qatar and about the factors that influence their attitudes. In addition, information related to pharmacy students' perceived barriers for PC provision is lacking. Knowing this important information will assist in monitoring the progress in training future pharmacy practitioners in Qatar. 


\section{Study aims}

The study objectives were to investigate Qatar pharmacy students' attitudes toward PC, to identify the factors that influence their attitudes toward PC, and to recognize their perceived barriers for PC provision in Qatar.

\section{Methods}

\section{Study design and participants}

QU College of Pharmacy is the only pharmacy degree program in the country. The study objectives were addressed in a cross-sectional survey of pharmacy students at QU College of Pharmacy. Eligible participants were all QU second, third, and fourth professional (final) year pharmacy students (52 female students). First year pharmacy students were not exposed to the concept of $\mathrm{PC}$ at the time of survey administration, and as a result, this group of students was excluded.

\section{Assessment tool}

A self-administered survey was used in the study. The study investigators designed the study survey based, in part, on the standard Pharmaceutical Care Attitudes Survey (PCAS). This survey tool is a validated instrument that measures students' attitudes toward PC. It was developed in the United States and has already been used and tested in previous studies in Nigeria, the Kingdom of Saudi Arabia, and the United States. ${ }^{19,28-31}$

The draft survey was distributed to eight faculty members at QU College of Pharmacy to assess its readability and content validity. It was also pretested among a group of four randomly selected pharmacy students at QU College of Pharmacy for clarity, relevance, acceptability, and time to completion (ie, face validity). These four students were excluded from the final study sample. Refinements were made as required in terms of language comprehension and question organization before distributing the final survey to the study population.

The final structured survey consisted of a total of 11 (closed- and open-ended) questions that could be completed within 10 minutes. It contained questions that addressed the pharmacy students' attitudes towards PC based on the PCAS survey, the students' sociodemographic characteristics, their perceived barriers toward $\mathrm{PC}$ provision, and their suggestions to improve their attitudes towards PC. Sociodemographic characteristics included age, country of origin, current professional year, marital status, and pharmacy training experience (Table 1).

To assess the students' attitudes towards PC, a fivepoint Likert scale (rating from $1=$ strongly disagree to
Table I Respondent sociodemographic characteristics

\begin{tabular}{ll}
\hline Characteristic & $\begin{array}{l}\text { Frequency } \\
\text { (percentage) }\end{array}$ \\
\hline Country of origin (N=46) & \\
Algeria & $3(7 \%)$ \\
Egypt & $6(13 \%)$ \\
Eritrea & $1(1 \%)$ \\
Iraq & $5(11 \%)$ \\
Jordan & $6(13 \%)$ \\
Libya & $3(7 \%)$ \\
Palestine & $10(22 \%)$ \\
Qatar & $2(4 \%)$ \\
Somalia & $2(4 \%)$ \\
Sudan & $3(7 \%)$ \\
Syria & $3(7 \%)$ \\
Yemen & $2(4 \%)$ \\
Current professional pharmacy year (N=46) & \\
Second & $20(44 \%)$ \\
Third & $12(26 \%)$ \\
Four & $14(30 \%)$ \\
Marital status (N=46) & \\
Unmarried & $45(98 \%)$ \\
Married & $1(2 \%)$ \\
Past training experience in a pharmacy & \\
environment including SPEP (N=46) & \\
Yes &
\end{tabular}

Abbreviation: SPEP, structured practical experience in pharmacy.

$5=$ strongly agree) was utilized to measure the extent to which the students agreed with 13 statements related to PC (Tables 2 and 3). These statements were taken directly from the PCAS survey and measure three constructs: professional benefit (statements 4, 5, and 7-12), professional duty (statements 1-3), and return on effort (statements 6 and 13). Eleven of the 13 statements were positively worded, and two were negatively worded ("Time" and "Add Work"): the two negatively worded items, which relate to return on effort, were reverse scored during analysis so that the more positive attitudes toward PC would be reflected by higher scores.

The barriers that would prevent QU pharmacy students from providing $\mathrm{PC}$ in the future were identified by listing 12 possible barriers and by asking the students to indicate on a three-point Likert scale (high, medium, and low) the extent to which each of the listed barriers would impede their PC provision in the future. The barriers included: inadequate drug information resources, lack of access to the 
Table 2 Students' attitudes towards pharmaceutical care per PCAS item

\begin{tabular}{|c|c|c|c|c|c|c|c|}
\hline \multirow[t]{3}{*}{ Statement } & \multirow{2}{*}{\multicolumn{5}{|c|}{$\begin{array}{l}\text { Frequency (percentage) } \\
\text { Please indicate your extent of agreement with } \\
\text { the following statements regarding your attitudes } \\
\text { towards pharmaceutical care }\end{array}$}} & \multirow{3}{*}{$\begin{array}{l}\text { Mean } \pm \text { SD } \\
(95 \% \mathrm{Cl})\end{array}$} & \multirow{3}{*}{$\begin{array}{l}\text { Median } \\
\text { (IQR) }\end{array}$} \\
\hline & & & & & & & \\
\hline & $\begin{array}{l}\text { Strongly } \\
\text { agree }\end{array}$ & Agree & Neutral & Disagree & $\begin{array}{l}\text { Strongly } \\
\text { disagree }\end{array}$ & & \\
\hline $\begin{array}{l}\text { I. All pharmacists should perform } \\
\text { pharmaceutical care }\end{array}$ & $24(52 \%)$ & 18 (39\%) & $4(9 \%)$ & $0(0 \%)$ & $0(0 \%)$ & $\begin{array}{l}4.43 \pm 0.65 \\
(4.24-4.63)\end{array}$ & $5(4-5)$ \\
\hline $\begin{array}{l}\text { 2. Primary responsibility of pharmacists } \\
\text { in health care setting should be to prevent } \\
\text { and solve medication-related problems }\end{array}$ & 29 (63\%) & 17 (37\%) & $0(0 \%)$ & $0(0 \%)$ & $0(0 \%)$ & $\begin{array}{l}4.63 \pm 0.49 \\
(4.48-4.76)\end{array}$ & $5(4-5)$ \\
\hline $\begin{array}{l}\text { 3. Pharmacists' primary responsibility should } \\
\text { be to practice pharmaceutical care }\end{array}$ & 17 (37\%) & I 8 (39\%) & 10 (22\%) & $0(0 \%)$ & I (2\%) & $\begin{array}{l}4.11 \pm 0.82 \\
(3.87-4.33)\end{array}$ & $4(3.75-5)$ \\
\hline $\begin{array}{l}\text { 4. Pharmacy students can perform } \\
\text { pharmaceutical care during their clerkship }\end{array}$ & 15 (32\%) & 32 (50\%) & $4(9 \%)$ & I (2\%) & $3(7 \%)$ & $\begin{array}{l}4.04 \pm 0.94 \\
(3.74-4.30)\end{array}$ & $4(4-5)$ \\
\hline $\begin{array}{l}\text { 5. I think the practice of pharmaceutical } \\
\text { care is valuable }\end{array}$ & 31 (67\%) & 15 (33\%) & $0(0 \%)$ & $0(0 \%)$ & $0(0 \%)$ & $\begin{array}{l}4.67 \pm 0.47 \\
(4.52-4.80)\end{array}$ & $5(4-5)$ \\
\hline $\begin{array}{l}\text { 6. Providing pharmaceutical care takes } \\
\text { too much time and effort }{ }^{\mathrm{a}}\end{array}$ & 10 (22\%) & $25(54 \%)$ & $9(20 \%)$ & $0(0 \%)$ & $2(4 \%)$ & $\begin{array}{l}2.06 \pm 0.77 \\
(1.85-2.30)\end{array}$ & $2(2-2.25)$ \\
\hline $\begin{array}{l}\text { 7. I would like to perform pharmaceutical } \\
\text { care as a pharmacist practitioner }\end{array}$ & $26(57 \%)$ & I 8 (39\%) & $2(4 \%)$ & $0(0 \%)$ & $0(0 \%)$ & $\begin{array}{l}4.52 \pm 0.59 \\
(4.35-4.70)\end{array}$ & $5(4-5)$ \\
\hline $\begin{array}{l}\text { 8. Providing pharmaceutical care is } \\
\text { professionally rewarding }\end{array}$ & $26(56 \%)$ & 17 (37\%) & $3(7 \%)$ & $0(0 \%)$ & $0(0 \%)$ & $\begin{array}{l}4.5 \pm 0.62 \\
(4.30-4.67)\end{array}$ & $5(4-5)$ \\
\hline $\begin{array}{l}\text { 9. I feel that the pharmaceutical care is the right } \\
\text { direction for the provision to be headed }\end{array}$ & $26(56 \%)$ & $16(35 \%)$ & $4(9 \%)$ & $0(0 \%)$ & $0(0 \%)$ & $\begin{array}{l}4.48 \pm 0.66 \\
(4.28-4.67)\end{array}$ & $5(4-5)$ \\
\hline $\begin{array}{l}\text { 10. I feel that pharmaceutical care movement } \\
\text { would benefit pharmacists }\end{array}$ & 27 (59\%) & 17 (37\%) & $2(4 \%)$ & $0(0 \%)$ & $0(0 \%)$ & $\begin{array}{l}4.54 \pm 0.58 \\
(4.37-4.72)\end{array}$ & $5(4-5)$ \\
\hline $\begin{array}{l}\text { II. I feel that pharmaceutical care movement } \\
\text { will improve patient health }\end{array}$ & 32 (70\%) & 14 (30\%) & $0(0 \%)$ & $0(0 \%)$ & $0(0 \%)$ & $\begin{array}{l}4.69 \pm 0.46 \\
(4.56-4.83)\end{array}$ & $5(4-5)$ \\
\hline $\begin{array}{l}\text { 12. I feel that practicing pharmaceutical care } \\
\text { will benefit my professional pharmacy } \\
\text { career as a pharmacy practitioner }\end{array}$ & 30 (65\%) & 15 (33\%) & I (2\%) & $0(0 \%)$ & $0(0 \%)$ & $\begin{array}{l}4.63 \pm 0.53 \\
(4.48-4.78)\end{array}$ & $5(4-5)$ \\
\hline $\begin{array}{l}\text { 13. Providing pharmaceutical care is not } \\
\text { worth the additional workload that } \\
\text { it places on the pharmacist }{ }^{\mathrm{a}}\end{array}$ & $2(4 \%)$ & $4(9 \%)$ & $6(13 \%)$ & $13(28 \%)$ & 21 (46\%) & $\begin{array}{l}3.85 \pm 1.07 \\
(0.77-1.28)\end{array}$ & $4(3-5)$ \\
\hline
\end{tabular}

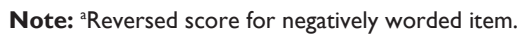

Abbreviations: $\mathrm{Cl}$, confidence interval; IQR, interquartile range; PCAS, Pharmaceutical Care Attitudes Survey; SD standard deviation.

patient medical record in the pharmacy, lack of therapeutics knowledge, lack of understanding PC, inadequate training in PC, lack of workplace for counseling in the pharmacy, inadequate technology in the pharmacy, time constraints, and other barriers (Table 4).

The survey was started with the definition of "pharmaceutical care": "Pharmaceutical care is a patient centered

Table 3 Students' attitudes towards pharmaceutical care per PCAS scale

\begin{tabular}{lrlll}
\hline Scale & Mean \pm SD & $\begin{array}{l}\text { Minimum } \\
\text { score }\end{array}$ & $\begin{array}{l}\text { Maximum } \\
\text { score }\end{array}$ & Range \\
\hline Professional duty & $13.17 \pm 1.65$ & 10 & 15 & 5 \\
Professional benefit & $36.08 \pm 3.68$ & 28 & 40 & 12 \\
Return on effort & $5.91 \pm 1.53$ & 2 & 9 & 7 \\
\hline
\end{tabular}

Abbreviations: PCAS, Pharmaceutical Care Attitudes Survey; SD standard deviation. practice in which the practitioner assumes responsibility for patients' drug-related needs and is held accountable for this commitment."1

\section{Survey implementation and confidentiality}

The survey was conducted using the Web-based commercially available survey software, SurveyMonkey ${ }^{\circledR}$ (SurveyMonkey, Palo Alto, CA, USA). ${ }^{32}$

Web-based surveys are efficient and convenient alternatives to the more traditional methods of data collection. They assure short timeframe for collection of responses and are time and cost saving. Furthermore, they permit anonymity, in addition to rapid and effective data analysis. ${ }^{33}$

An email, containing an Internet link to the survey, was sent to all eligible participants. The participants submitted 
Table 4 Students' perceived barriers for PC provision

\begin{tabular}{|c|c|c|c|}
\hline \multirow[t]{3}{*}{ Barrier } & \multirow{2}{*}{\multicolumn{3}{|c|}{$\begin{array}{l}\text { Frequency (percentage) } \\
\text { To what extent would each of } \\
\text { the following barriers prevent } \\
\text { you from providing PC when } \\
\text { you become a pharmacist in the } \\
\text { future? }\end{array}$}} \\
\hline & & & \\
\hline & $\begin{array}{l}\text { High } \\
\text { extent }\end{array}$ & $\begin{array}{l}\text { Moderate } \\
\text { extent }\end{array}$ & $\begin{array}{l}\text { Low } \\
\text { extent }\end{array}$ \\
\hline $\begin{array}{l}\text { Inadequate drug information } \\
\text { resources in the pharmacy }\end{array}$ & $25(55 \%)$ & $14(30 \%)$ & $7(15 \%)$ \\
\hline $\begin{array}{l}\text { Lack of access to the patient } \\
\text { medical record in the pharmacy }\end{array}$ & 35 (76\%) & II (24\%) & $0(0 \%)$ \\
\hline Lack of therapeutics knowledge & 18 (39\%) & II (24\%) & $17(37 \%)$ \\
\hline $\begin{array}{l}\text { Lack of understanding } \\
\text { of pharmaceutical care }\end{array}$ & 17 (37\%) & $9(20 \%)$ & $20(43 \%)$ \\
\hline $\begin{array}{l}\text { Inadequate training } \\
\text { in pharmaceutical care }\end{array}$ & $16(35 \%)$ & $14(30 \%)$ & $16(35 \%)$ \\
\hline $\begin{array}{l}\text { Lack of workplace for } \\
\text { counseling in the pharmacy }\end{array}$ & 20 (44\%) & $19(41 \%)$ & 7 (15\%) \\
\hline $\begin{array}{l}\text { Inadequate technology } \\
\text { in the pharmacy }\end{array}$ & $20(43.5 \%)$ & $20(43.5 \%)$ & $6(13 \%)$ \\
\hline Lack of self confidence & 15 (33\%) & $12(26 \%)$ & 19 (4I\%) \\
\hline Time constraints & $24(53 \%)$ & $17(38 \%)$ & $4(9 \%)$ \\
\hline $\begin{array}{l}\text { Poor image of pharmacist's } \\
\text { role in society }\end{array}$ & $23(50 \%)$ & $14(30 \%)$ & $9(20 \%)$ \\
\hline $\begin{array}{l}\text { Inability to deal with a } \\
\text { different gender }\end{array}$ & II (24\%) & $6(13 \%)$ & $29(63 \%)$ \\
\hline Religious constraints & 7 (I5\%) & $3(7 \%)$ & $36(78 \%)$ \\
\hline
\end{tabular}

Abbreviation: PC, pharmaceutical care.

the survey online. A reminder was sent via email to all eligible participants 2 weeks after the initial email was sent. After 4 weeks of data collection, the survey was closed, and the data were entered into the online survey software.

To minimize any potential for bias and to protect participant confidentiality, the survey was anonymously completed; no participant identification information was recorded by the investigators.

\section{Data analysis}

Online survey data were downloaded to an Excel $^{\circledR}$ (Microsoft Corporation, Redmond, WA, USA) spreadsheet, and imported into SPSS (IBM Corporation, Armonk, NY, USA) software, version 18, for descriptive and inferential analysis. Association of the sociodemographic characteristics of the respondents with their attitudes toward PC was determined using Spearman's rho test. Association was considered statistically significant when $P$ was $<0.05$.

Incomplete surveys were included in the analysis if they contained basic demographic information and partial responses to some of the questions. Accordingly, the number of respondents for each question varied.
Table 5 Statistically significant correlation between students characteristics and their attitudes toward pharmaceutical care ${ }^{a}$

\begin{tabular}{|c|c|c|}
\hline & $\begin{array}{l}\text { F } \\
\text { (Spearman's } \\
\text { rho) }\end{array}$ & $\begin{array}{l}\text { P-values }<0.05 \\
\text { (Spearman's } \\
\text { rho) }\end{array}$ \\
\hline $\begin{array}{l}\text { Professional year versus } \\
\text { "Primary responsibility of } \\
\text { pharmacists in health care setting } \\
\text { should be to prevent and solve } \\
\text { medication-related problems" }\end{array}$ & -0.320 & 0.030 \\
\hline $\begin{array}{l}\text { Professional year versus } \\
\text { "I think the practice of } \\
\text { pharmaceutical care is valuable" }\end{array}$ & -0.318 & 0.031 \\
\hline $\begin{array}{l}\text { Professional year versus "I feel that } \\
\text { pharmaceutical care movement } \\
\text { will improve patient health" }\end{array}$ & -0.373 & 0.011 \\
\hline $\begin{array}{l}\text { Professional year versus "I feel that } \\
\text { practicing pharmaceutical care will } \\
\text { benefit my professional pharmacy } \\
\text { career as a pharmacy practitioner" }\end{array}$ & -0.299 & 0.044 \\
\hline $\begin{array}{l}\text { Weeks of practical experience } \\
\text { versus "Primary responsibility of } \\
\text { pharmacists in health care setting } \\
\text { should be to prevent and solve } \\
\text { medication-related problems" }\end{array}$ & -0.416 & 0.005 \\
\hline $\begin{array}{l}\text { Weeks of practical experience } \\
\text { versus "Pharmacy students can } \\
\text { perform pharmaceutical care } \\
\text { during their clerkship" }\end{array}$ & -0.363 & 0.016 \\
\hline $\begin{array}{l}\text { Weeks of practical experience } \\
\text { versus "I think the practice of } \\
\text { pharmaceutical care is valuable" }\end{array}$ & -0.412 & 0.005 \\
\hline $\begin{array}{l}\text { Weeks of practical experience } \\
\text { versus "I feel that pharmaceutical } \\
\text { care movement will improve } \\
\text { patient health" }\end{array}$ & -0.412 & 0.005 \\
\hline $\begin{array}{l}\text { Weeks of practical experience } \\
\text { versus "I feel that practicing } \\
\text { pharmaceutical care will benefit } \\
\text { my professional pharmacy career } \\
\text { as a pharmacy practitioner" }\end{array}$ & -0.327 & 0.03 \\
\hline
\end{tabular}

Note: anly statistically significant correlations between student characteristics and their pharmaceutical care attitudes are included in this table.

The mean, standard deviation, median, interquartile range, and percentage frequency for each of the PCAS items was determined (Table 2). The mean, standard deviation, and range for the three separate constructs were determined (Table 3). The score for each scale of the PCAS was calculated by adding the five Likert scores (1-5) of the related items: professional benefit, items 4,5 , and 7-12; professional duty, items 1-3; return on effort, items 6 and 13 . Scores above 3.5 were interpreted to be positive responses. The highest possible score for professional benefit was 40 , and 8 was the lowest; the highest possible score for professional duty was 15 , and 3 was the lowest; and the 
highest possible score for return on effort was 10, and 2 was the lowest.

\section{Ethical considerations}

Participation in the study did not pose any risk to participants and was voluntary. Pharmacy students who completed the survey were considered to have given the consent for participation in the study. The study procedures and instruments were exempted from full ethics review by the QU Institutional Review Board.

\section{Results}

Over the 4-week study period, of the 52 students, 46 completed the survey (achieved overall response rate was 88\%). Response rate was $100 \%$ for second-year students, $86 \%$ for third-year students, and $77 \%$ for fourth-year students.

\section{Students' sociodemographic characteristics}

The sociodemographic characteristics of respondents are summarized in Table 1. Most respondents were coming from one of four countries: Palestine, Jordan, Egypt, and Iraq (59\%). Respondents were aged between 19 and 24 years, with a mean age of 21 years \pm standard deviation of 1.33 years. The average number of weeks of training for respondents was 9 weeks \pm standard deviation of 6 weeks.

\section{Students' attitudes toward PC}

QU pharmacy students' attitudes toward each PC item are presented in Table 2. Overall, the students had very positive attitudes toward PC provision. All respondents agreed that the primary responsibility of pharmacists in the health care setting should be to prevent and solve medication-related problems, that the practice of $\mathrm{PC}$ is valuable, and that the $\mathrm{PC}$ movement will improve patient health. However, $76 \%$ of respondents believed that providing PC takes too much time and effort.

The mean \pm standard deviation scores on the PCAS scales are summarized in Table 3. An assessment of influence of sociodemographic characteristics of the respondents on their attitudes toward PC is presented in Table 5.

Professional year and practical experience duration were inversely significantly associated with four and five statements, respectively, out of the 13 PCAS statements, including the statements related to the value of PC and its benefit in improving patient health and pharmacy practitioners' careers. No statistically significant correlations existed between other sociodemographic characteristics and students' attitudes toward PC.

\section{Students' perceived barriers for PC provision}

Highly perceived barriers for PC provision included lack of access to the patients' medical records in the pharmacy ( $76 \%$ of respondents), inadequate drug information sources in the pharmacy (55\%), time constraints (53\%), and poor image of the pharmacist's role in society $(50 \%)$ (Table 4$)$.

When asked about the changes in pharmacy curriculum that should be made to further enhance their attitudes toward $\mathrm{PC}$, most respondents suggested increasing the number of PC exercises in the professional skills course series (78\% of respondents) and in the SPEP Program (74\%).

\section{Discussion}

This study is the first of its kind to assess the attitudes of Qatar pharmacy students toward PC. Overall, students in this study had high positive attitudes toward PC. There are other, but few studies describing pharmacy student attitudes toward PC. Both American and Saudi pharmacy students indicate favorable positive attitudes toward PC and agree that that all pharmacists should perform PC. ${ }^{29,31}$ Although our curriculum does not include a separate course on PC, this did not appear to be essential to nurture the students' positive attitudes.

Data in our study suggest that participants who have more practical experience have less positive attitudes toward PC. Professional pharmacy year is another contributing factor. Participants who are early in their professional years have higher positive attitudes toward PC. This is not unexpected for Qatar pharmacy students. It is plausible that those students who have completed more clerkships realize the possible mismatch between what is taught at QU College of Pharmacy and how pharmacists practice in Qatar. The pharmacy sites used for clinical clerkships are not yet offering PC services. As a result, our students are not able to observe the incorporation of $\mathrm{PC}$ into routine pharmacy practice.

One of the basic ways by which a new behavior is gained is through observation of other people's behavior and the outcomes for them. ${ }^{34}$ Therefore, if pharmacy students are exposed to training in which the pharmacy practice is mostly passive, they are not likely to assume an active practice in which complete PC is provided. This highlights the need to have pharmacy experiential training sites that are designed to prepare Qatar pharmacy students for PC practice. These sites should offer the students the chance to see the integration of PC into pharmacy practice. The question comes up about how to change the current pharmacy training sites to actively promote PC. There are several ways to answer this question. 
One way is to offer workshops to pharmacy preceptors to be role model pharmacists who can demonstrate and teach exemplary PC practice. These workshops can be prepared and delivered by the QU College of Pharmacy Continuing Pharmacy Professional Development program. These workshops should include a mix of knowledge and interactive skill development sessions with follow-up application at the preceptor practice site.

In addition to preceptor training, pharmacy students should be afforded the opportunity to provide PC directly to actual patients under observation of experienced preceptors as an integral portion of their training experience. The students should be engaged in the entire patient care process from initial assessment through documentation to follow-up evaluation. Students can then review their own performance with their pharmacy preceptors to determine their command of the PC concept. The major goals of these interactions are to help students develop patient assessment, care planning and evaluation skills, and to teach them the importance of developing an appreciation for the significant role they can play as pharmacists.

The top perceived barrier for PC provision is lack of access to patient medical records in the pharmacy. Difficulty in accessing patients' clinical and laboratory data has also been reported as a barrier for PC provision in community pharmacies worldwide. ${ }^{12,35} \mathrm{PC}$ is a multifaceted process that involves identifying, preventing, and resolving drug therapy problems. Associated with this process is the delivery of proper pharmaceutical services, which include obtaining patient history, evaluating laboratory data, and reviewing patient records. ${ }^{22}$ In Qatar, patients' medical and medication information is only available in hospitals and health care clinics. This emphasizes the need for having patient medical records in Qatar pharmacies to provide an opportunity for developing a scope of PC.

Another of the students' perceived barriers for PC provision is the poor image of the pharmacist role in Qatar's society. Expanding scope of pharmacy practice in Qatar necessitates positive public attitudes and views. One survey of a small sample of the general population in Qatar found that "the public has a poor understanding of the pharmacist's role in regards to monitoring drug therapy, performing health screening, and providing drug information." ${ }^{36}$ This is unfortunate, as many studies have demonstrated the effectiveness of pharmacist delivered PC services with regard to clinical, humanistic, and economic outcomes in different disease conditions. ${ }^{37-39}$ More initiatives must be executed to educate Qatar's population about the importance of PC and to promote the pharmacist's role through media campaigns and increased support from Qatar's Supreme Council of Health.

The students also identified lack of time as an impediment in the delivery of PC. This barrier has also been reported in previous studies among pharmacists in Argentina, China, Northern Ireland, and Qatar. ${ }^{13,14,35,40}$ Markedly, with two or less pharmacists and less than one technician per pharmacy, and the high number of prescriptions dispensed, the perceived barrier of insufficient time to implement PC is reasonable and understandable. For Qatar pharmacists to implement PC practice, more pharmacy technicians need to be hired and better demarcation should exist between their role and that of pharmacists in this country. If Qatar pharmacists can be exempted to some extent from performing the routine dispensing tasks which can be delegated with supervision to trained pharmacy technicians, they can have more time and attention for cognitive services.

Another perceived barrier is inadequate drug information sources in the pharmacy. This is consistent with the results of a previous study conducted by one of the faculty members at QU College of Pharmacy about the characteristics of community pharmacies in Qatar. This study has confirmed that Qatar pharmacies have limited access to electronic resources and have a very small number of hardcopy drug information resources. ${ }^{41}$ The implementation of PC in Qatar will necessitate supporting these pharmacies with all the needed tools that facilitate patient care, including drug information resources.

\section{Limitations}

This study had some inherent limitations. Data presented here are a self-report of the students' attitudes to PC. In addition, despite our high response rate, our results of positive attitudes towards PC are from pharmacy students in Qatar and may not be shared by students from other pharmacy colleges in the Middle East that may follow a traditional pharmaceutical sciences-based curriculum.

\section{Conclusion}

Qatar Pharmacy students have good attitudes toward PC. The top perceived barriers to PC provision are lack of access to patient medical records, inadequate drug information sources in the pharmacy, lack of time, and poor pharmacist image in society. Efforts should be exerted to overcome these perceived barriers, including better designing of pharmacy training sites to give pharmacy students the chance to observe the integration of $\mathrm{PC}$ into practice. 


\section{Disclosure}

The authors report no conflicts of interest in this work.

\section{References}

1. Hepler CD, Strand LM. Opportunities and responsibilities in pharmaceutical care. Am J Hosp Pharm. 1990;47(3):533-543.

2. Neto PR, Marusic S, de Lyra Junior DP, et al. Effect of a 36-month pharmaceutical care program on the coronary heart disease risk in elderly diabetic and hypertensive patients. J Pharm Pharm Sci. 2011;14(2): 249-263.

3. Clifford RM, Davis WA, Batty KT, Davis TM; Fremantle Diabetes Study. Effect of a pharmaceutical care program on vascular risk factors in type 2 diabetes: the Fremantle Diabetes Study. Diabetes Care. 2005; 28(4):771-776.

4. Bunting BA, Cranor CW. The Asheville Project: long-term clinical, humanistic, and economic outcomes of a community-based medication therapy management program for asthma. J Am Pharm Assoc. 2006; 46(2):133-147.

5. Cranor CW, Bunting BA, Christensen DB. The Asheville Project: longterm clinical and economic outcomes of a community pharmacy diabetes care program. J Am Pharm Assoc (Wash). 2003;43(2):173-184.

6. Draft statement on pharmaceutical care. ASHP Council on Professional affairs. American Society of Hospital Pharmacists. Am J Hosp Pharm. 1993;50(1):126-128.

7. APhA house of delegates endorses policies on pharmaceutical care, therapeutic outcomes, compounding, packaging. Am J Hosp Pharm. 1992;49(6): 1318.

8. International Pharmaceutical Federation. FIP Statement of Professional Standards Pharmaceutical Care. The Hague: International Pharmaceutical Federation; 1998. Available from: http://www.fip.org/www/uploads/ database_file.php?id=269\&table_id=. Accessed April 25, 2013.

9. May RM. Barriers to pharmaceutical care in acute care setting. Am J Hosp Pharm. 1993;50:1608-1611.

10. Roberts AS, Benrimoj SI, Chen TF, Williams KA, Aslani P. Practice change in community pharmacy: quantification of facilitators. Ann Pharmacother. 2008;42(6):861-868.

11. McDonough RP, Rovers JP, Currie JD. Obstacles to the implementation of pharmaceutical care in the community setting. J Am Pharm Assoc. 1998;38:87-95.

12. Ngorsuraches S, Li SC. Thai pharmacists' understanding, attitudes, and perceived barriers related to providing pharmaceutical care. Am J Health Syst Pharm. 2006;63(21):2144-2150.

13. Uema SA, Vega EM, Armando PD, Fontana D. Barriers to pharmaceutical care in Argentina. Pharm World Sci. 2008;30(3):211-215.

14. Fang Y, Yang S, Feng B, Ni Y, Zhang K. Pharmacists' perception of pharmaceutical care in community pharmacy: a questionnaire survey in Northwest China. Health Soc Care Community. 2011;19(2):189-197.

15. Hatwig CA, Crane VS, Hayman JN. A pharmaceutical care challenge: recruiting, training, and retaining pharmaceutical care practitioners. Top Hosp Pharm Manage. 1993;13(3):1-10.

16. Kane MP, Briceland LL, Hamilton RA. Solving drug related problems in the professional experience program. Am J Pharm Educ. 1993;57: 347-351.

17. Briceland LL, Hamilton RA, Kane MP. Pharmacy students' experience with identifying and solving drug-related problems during clinical clerkship. Am J Hosp Pharm. 1993;50(2):294-296.

18. Chisholm MA, Hawkins DW. Analysis of pharmacotherapy recommendations provided by Doctor of Pharmacy clerkship students. J Pharm Teaching. 1997;5(4):3-12.

19. Chisholm MA, Wade WE. Factors influencing students' attitudes toward pharmaceutical care. Am J Health Syst Pharm. 1999;56(22): 2330-2335.
20. Chisholm MA, Wade WE. Using actual patients in classroom to develop positive students' attitudes toward pharmaceutical care. Am J Pharm Educ. 1999;63:296-299.

21. Kennedy DT, Ruffin DM, Goode JV, Small RE. The role of academia in community-based pharmaceutical care. Pharmacotherapy. 1997;17(6):1352-1356.

22. Schommer JC, Cable GL. Current status of pharmaceutical care practice: strategies for education. Am J Pharm Educ. 1996;60:36-42.

23. Wikipedia [homepage on the Internet]. Qatar. Available from: http:// en.wikipedia.org/wiki/Qatar. Accessed December 9, 2013.

24. El Hajj M, Kheir AN, Al-Zaidan MB, Jewesson PJ. Pharmacist characteristics, medication use perceptions and professional satisfaction: a first national survey in the state of Qatar. J Healthcare Leadership. 2011;3:9-28.

25. Hamad Medical Corporation [homepage on the Internet]. Annual health report 2012. Qatar: Hamad Medical Corporation; 2013. Available from: http://site.hmc.org.qa/msrc/AHR2012/2012.html. Accessed December 9, 2013.

26. El Hajj M, Al-Saeed H, Khaja M. Qatar pharmacists' understanding, attitudes, practice and perceived barriers related to providing pharmaceutical care. Proceedings of the 2011 ACCP Annual Meeting, Pittsburgh, PA, USA. 2011:363e-364e.

27. Qatar University College of Pharmacy. http://www.qu.edu.qa/ pharmacy/index.php. Accessed December 9, 2013.

28. Al-Arifi MN. Pharmacy students' attitudes toward pharmaceutical care in Riyadh region Saudi Arabia. Pharm World Sci. 2009;31(6):677-681.

29. Chisholm MA, Martin BC. Development of an instrument to measure student attitudes concerning pharmaceutical care. Am J Pharm Educ. 1997;61:374-379.

30. Martin BC, Chisholm MA. Cross-validation of an instrument measuring students attitudes toward pharmaceutical care. Am J Pharm Educ. 1999;63:46-51.

31. Udeogaranya PO, Ukwe CV, Ekwunife OI. Assessment of attitudes of University of Nigeria pharmacy students toward pharmaceutical care. Pharm Pract. 2009;7(3):145-149.

32. SurveyMonkey. http://www.surveymonkey.com/. Accessed April 25, 2013.

33. Lefever S, Dal M, Matthíasdóttir A. Online data collection in academic research: advantages and limitations. Br J Educ Technol. 2007;38(4):574-582.

34. Bandura A. Social Foundations of Thought and Action: A Social Cognitive Theory. Englewood Cliffs, NJ: Prentice Hall Inc.; 1986:1-105.

35. Farris KB, Fernandez-Llimos F, Benrimoj SI. Pharmaceutical care in community pharmacies: practice and research from around the world. Ann Pharmacother. 2005;39(9):1539-1541.

36. El Hajj MS, Salem S, Mansoor H. Public's attitudes towards community pharmacy in Qatar: a pilot study. Patient Prefer Adherence. 2011;5:405-422.

37. Mangiapane S, Schulz M, Muhlig S, Ihle P, Schubert I, Waldmann HC. Community pharmacy-based pharmaceutical care for asthma patients. Ann Pharmacother. 2005;39(11):1817-1822.

38. Morello CM, Zadvorny EB, Cording MA, Suemoto RT, Skog J, Harari A. Development and clinical outcomes of pharmacist-managed diabetes care clinics. Am J Health Syst Pharm. 2006;63(14):1325-1331.

39. Okamoto MP, Nakahiro RK. Pharmacoeconomic evaluation of a pharmacist-managed hypertension clinic. Pharmacotherapy. 2001;21(11):1337-1344.

40. Bell HM. McElnay JC, Hughes CM, et al. A quantitative investigation of the attitudes and opinion of community pharmacist to pharmaceutical care. J Soc Adm Pharm. 1998;15:284-295.

41. Ahmed H, Al-Warad, Javed B. Assessing community pharmacy characteristics in Qatar. Poster presented at: Qatar Health 2010 International Healthcare Congress and Exhibition; December 10-15, 2010; Doha, Qatar. 
Therapeutics and Clinical Risk Management

Dovepress

\section{Publish your work in this journal}

Therapeutics and Clinical Risk Management is an international, peerreviewed journal of clinical therapeutics and risk management, focusing on concise rapid reporting of clinical studies in all therapeutic areas, outcomes, safety, and programs for the effective, safe, and sustained use of medicines. This journal is indexed on PubMed Central, CAS,
EMBase, Scopus and the Elsevier Bibliographic databases. The manuscript management system is completely online and includes a very quick and fair peer-review system, which is all easy to use. Visit http://www.dovepress.com/testimonials.php to read real quotes from published authors.

Submit your manuscript here: http://www.dovepress.com/therapeutics-and-clinical-risk-management-journal 